American Journal of Economics and Business Administration 1 (2): 177-181, 2009

ISSN 1945-5488

(C) 2009 Science Publications

\title{
Impact of University Budget Cuts on the Local Economy: Case for a Regional University
}

\author{
Kalyan Chakraborty \\ Department of Accounting Information System, School of Business, \\ Emporia State University, Box 4057, 1200 Commercial Street, Emporia KS 66801
}

\begin{abstract}
Problem statement: Considering the economic downturn and state-wide revenue shortfall almost all of the states have reduced their spending on higher education. The problem addressed in this study was to assess the economic impact of university budget reductions on the local and state economy of Kansas. Approach: The study used regional multipliers from an input-output model developed by Bureau of Economic Analysis, RIMS-II and applied to the budget reduction dataset supplied by the Office of Budget, Emporia State University, Kansas. Due to a statewide revenue shortfall of \$200 million for the fiscal year 2009-10, Kansas state legislators have drastically cut back their support for higher education. Emporia State University reduced its spending by $\$ 4.203$ million which includes elimination of 79 full and part-time employees. Results: Using economic impact multipliers this study found that for every dollar decrease in spending by ESU, output and income will be reduced by $\$ 1.04$ and $\$ 0.65$, respectively in the Emporia Area and by $\$ 1.56$ and $\$ 0.85$, respectively for Kansas. The study also found that for every job loss at ESU an additional 0.61 jobs are lost in the Emporia Area and 0.89 jobs in Kansas economy. Conclusion: The implications of this study found that cutting funding for Emporia State University will eventually diminish its positive regional effect in terms of output, earnings and employment potential both in the short-run and in the long-run.
\end{abstract}

Key words: Economic impact, input-output model, regional, multiplier, budget

\section{INTRODUCTION}

Nationwide recession is impacting higher education funding. Virtually all states have announced some level of revenue shortfall for the current and the subsequent fiscal years. According to an estimate the total nationwide shortfall through 2011 is between $\$ 350$ billion and $\$ 370$ billion and could be even higher if job losses fail to stop soon ${ }^{[11]}$. For Kansas the revenue shortfall for FY 2009 is \$200 million and for FY 2010 it is expected to be $\$ 1$ billion. When state budgets are tight or there is a change in politics, generally higher education funding is cut by the legislators. Several states are reducing financial award sizes, eliminating grants and tightening eligibility conditions due to lack of funding while the number of students seeking financial aid is rising sharply ${ }^{[8]}$. According to the Center for Budget and Policy Priorities ${ }^{[2]} 32$ states have cut funding for public colleges and universities leading to a reduction in employment of faculty and staff and increasing tuition. For example, on June 25 the Kansas Board of Regents approved a 4\% tuition hike for Emporia State University (ESU) for FY 2010 in response to lawmakers' reduction in state appropriations to higher education by $10 \%$.
Colleges and universities in the US are attempting to educate more students with relatively fewer resources than ever before. Researchers found that if enrollment continues at the current rate and tuition increases at the rate of inflation then by 2015 the nation's colleges and universities will have a \$38 billion operating shortfall in 1995 dollars $^{[1]}$. Kansas ranks in the top 10 of states in terms of college enrollment but it is near the bottom of the Big-12 in terms of per student state funding. Further, state funding for higher education in Kansas, adjusted for inflation, keeps falling while college enrollment in FY 2009 is the highest ${ }^{[5]}$. Colleges and Universities often exert significant influence on the urban and regional communities in terms of income/expenditure flows and employment generation. These institutions of higher learning purchase goods and services, hire workers, produce and sell education, art, entertainment, housing and food services to the local population. These economic activities have a ripple (indirect/induced) effect on the local economy as other economic sectors continue to respond to the increased demand for additional goods and services. However, at times when university expenditures are reduced (i.e., the ESU budget cuts for $\$ 4.2$ million for FY-2010) the local and 
state economy is adversely affected with reduction in output, income and employment.

The objective of this study is to report the economic impact of budget cuts for a typical regional university in the Midwest on the local and state economy. The study uses ESU which is primarily a 4 year undergraduate regional university located in Emporia, a rural community of 26,800 people. With a student population of $6,100(75 \%$ are fulltime and residential), the primary objective of ESU is excellence in teaching, where creativity and research by the faculty are recognized and service to the community is encouraged. The study is timely and important because unlike the studies measuring the positive impact of university expenditures, university budget cuts act as a double edged sword. Because budget cuts in higher education come when law makers and governors struggle to balance budgets during recessionary impact of tax revenues, at the same time the demand for more classes and student aids increase due to rising job losses and more enrollments. For example, according to US Department of Education students' application for federal aid in the first quarter of 2009 increased by $25 \%$ compared to same period last year ${ }^{[8]}$.

\section{MATERIALS AND METHODS}

Economic impact of an institution begins when the institution spends money. The economic impact measures the direct economic impact of an institution's spending plus additional indirect spending in the economy due to direct spending. A multiplier summarizes the total impact that can be expected from a change in given economic activity. In other words, a multiplier shows the additional (or indirect) change to the economy resulting from each change in a selected industry. When a change takes place in one sector of the economy which is interdependent with all other economic sectors, its effects propagate throughout the system resulting in a larger total impact than the original change ${ }^{[6]}$. Multipliers can also be used to estimate output, income and job losses occurring in an economy as a result of reduction in expenditure by an educational institution. The magnitude of multipliers varies widely by industry and region. Regions with a diverse industry mix have higher multipliers; also industries that make extensive use of materials from within the boundaries of the state have higher statewide multipliers.

The most commonly used technique for forecasting the economic impact of a University system has been Leontief' ${ }^{[12]}$ input-output analysis.
Table 1: Summary of ESU projected budget cuts for FY 2009-10

\begin{tabular}{lcc}
\hline Description & Amount (\$) & Amount (\$) \\
\hline 1. Utilities & & 75,000 \\
2. Other operating expenditures & 159,680 & \\
Print and advertising & 199,600 & \\
Repairs and servicing & 219,560 & \\
Travel and professional development & 379,240 & \\
Professional and service fees & 179,640 & \\
Other contractual services & 339,320 & \\
Supplies and materials & 518,960 & \\
3. Equipment, including computers & & $1,996,000$ \\
Sub total & $2,132,463$ \\
Reduction of faculty/staff/student positions* & $4,203,463$ \\
Total budget cuts & & \\
\hline
\end{tabular}

Source: ESU Budget Office, June 2009; *: The amount includes reduction of 24 faculty positions, 6 unclassified admin and support positions, 8 classified admin and support positions, 27 student positions and 12-14 graduate assistantships

The input-output model breaks down the total University related expenditures into detailed economic sectors. Each sector is dependent to some degree upon other sectors. If there is a change in the level of activity in one sector this will directly or indirectly cause a change in the level of production in other regional sectors. The amount of economic activity among different economic sectors measures the degree of interrelationship between sectors. These interdependencies among regional economic sectors can be estimated through inter-industry or input-output analysis based on a transaction matrix and direct requirement matrix ${ }^{[3,4]}$.

Economic impact analysis using RIMS-II multipliers requires extensive detail on the sources and nature of expenditure data or for budget cuts the sources of expenditure reductions. One of the major tasks in an economic impact study is the identification of all direct cuts in the local economy by various sources. Table 1 reports University-related direct expenditure reductions.

\section{RESULTS}

Table 2 displays the disaggregation of the University's total budget cuts into 10 economic sectors, which is derived from an aggregation of 60 regional economic sectors (RIMS II). Out of a total reduction for $\$ 4.203$ million the decrease in expenditure in the Emporia Area is $\$ 2.942$ million. The major cut is observed in ESU payrolls which relate to the 'household' sector in Table 2.

Using the final demand inter-industry coefficient matrix, the indirect and induced impacts of ESU budget cuts are calculated. These indirect and induced impacts are the result of spending by businesses and households. The less-spending would continue to impact Kansas' economy by reducing employment, output and household incomes. Table 3 reports the estimated 
Am. J. of Economics and Business Administration, 1 (2): 177-181, 2009

impacts of final demand multipliers on output, earnings and employment for the Emporia area and Table 4 reports total impacts for ESU budget cuts for the entire state of Kansas (the sum of economic impacts for the Emporia area and outside the Emporia area).

The University's direct expenditure reduction of \$2.94 million in the Emporia area (Table 3) generates an indirect and induced effect causing a reduction of \$3.1 million in output, \$1.0 million in earnings and 39 jobs. These indirect and induced impacts when added to the initial decrease generate a loss of $\$ 6.0$ million in output, \$2.5 million in earnings and 102 jobs in the Emporia area. Table 4 reports the University's total budget cuts for $\$ 4.2$ million generates a reduction of $\$ 10.8$ million in output, $\$ 3.9$ million in earnings and 150 jobs (direct plus indirect effects) in the state economy.
Table 2: Reduction of ESU expenditure by economic sectors for FY 2009-10

\begin{tabular}{lll}
\hline Economic sectors $^{\mathrm{a}}$ & $\begin{array}{l}\text { Kansas total } \\
(\text { millions \$) }\end{array}$ & $\begin{array}{l}\text { Emporia area } \\
(\text { millions \$) }\end{array}$ \\
\hline Utilities & 0.075 & 0.052 \\
Manufacturing & 0.020 & 0.014 \\
Wholesale trade & 0.521 & 0.365 \\
Retail trade & 0.340 & 0.238 \\
Transportation and warehousing & 0.188 & 0.131 \\
Professional, sci. and technical services & 0.515 & 0.360 \\
Admn. and waste management services & 0.179 & 0.126 \\
Accommodation and food services & 0.033 & 0.023 \\
Other services & 0.200 & 0.140 \\
Households & 2.132 & 1.493 \\
Total & 4.203 & 2.942 \\
\hline
\end{tabular}

${ }^{a}$ : Out of twenty economic sectors in BEA-RIMS-II Multipliers Appendix-C, only those sectors affected by university budget cuts are reported above

Table 3: Economic impact of university budget cut on output, earnings and employment in the emporia area, FY 2009-10

\begin{tabular}{|c|c|c|c|c|}
\hline \multirow[b]{2}{*}{ Economic sectors } & \multicolumn{4}{|l|}{ Impacts } \\
\hline & Direct cuts (mill \$) & Output (mill \$) & Earnings (mill \$) & Employ (jobs) \\
\hline Utilities & 0.052 & 0.073 & 0.016 & 0.371 \\
\hline Manufacturing & 0.014 & 0.020 & 0.006 & 0.187 \\
\hline Wholesale trade & 0.365 & 0.510 & 0.161 & 4.581 \\
\hline Retail trade & 0.238 & 0.339 & 0.110 & 5.824 \\
\hline Transportation and warehousing & 0.131 & 0.132 & 0.000 & 0.010 \\
\hline Professional, sci. and technical services & 0.360 & 0.539 & 0.231 & 7.034 \\
\hline Admn. and waste management services & 0.126 & 0.182 & 0.073 & 3.595 \\
\hline Accommodation and food services & 0.023 & 0.033 & 0.010 & 0.577 \\
\hline Other services & 0.140 & 0.208 & 0.069 & 3.362 \\
\hline Households & 1.493 & 1.032 & 0.301 & 13.256 \\
\hline Sub-total & 2.942 & 3.068 & 0.976 & 38.798 \\
\hline Add initial change & & 2.942 & $1.493^{\mathrm{a}}$ & 63.160 \\
\hline Total impact & & 6.010 & 2.469 & 101.958 \\
\hline
\end{tabular}

${ }^{\mathrm{a}}$ : Direct household earnings; ${ }^{\mathrm{b}}:$ Approximately $66 \%$ of 41 student workers and $95 \%$ of 38 faculty and staff would have been living in the Emporia Area if they would have been hired by ESU in FY 2009-10

Table 4: Economic impact of university budget cut on output, earnings and employment in Kansas, FY 2009-10

\begin{tabular}{|c|c|c|c|c|}
\hline \multirow[b]{2}{*}{ Economic sectors } & \multicolumn{4}{|l|}{ Impacts } \\
\hline & Direct cuts (mill \$) & Output (mill \$) & Earnings (mill \$) & Employ (jobs) \\
\hline Utilities & 0.075 & 0.140 & 0.029 & 0.749 \\
\hline Manufacturing & 0.020 & 0.038 & 0.009 & 0.297 \\
\hline Wholesale trade & 0.521 & 0.943 & 0.255 & 7.610 \\
\hline Retail trade & 0.340 & 0.648 & 0.185 & 8.950 \\
\hline Transportation and warehousing & 0.179 & 0.393 & 0.088 & 3.168 \\
\hline Professional, sci. and technical services & 0.515 & 0.966 & 0.322 & 10.132 \\
\hline Admn. and waste management services & 0.181 & 0.329 & 0.106 & 4.946 \\
\hline Accommodation and food services & 0.033 & 0.061 & 0.018 & 0.928 \\
\hline Other services & 0.200 & 0.384 & 0.112 & 5.223 \\
\hline Households & 2.132 & 2.689 & 0.695 & 28.481 \\
\hline Sub-total & 4.203 & 6.590 & 1.817 & 70.484 \\
\hline Add Initial change & & 4.203 & $2.132^{\mathrm{a}}$ & $79.000^{\mathrm{b}}$ \\
\hline Total impact & & 10.793 & 3.949 & 149.484 \\
\hline
\end{tabular}

${ }^{\mathrm{a}}$ : Direct household earnings; ${ }^{\mathrm{b}}$ : Approximately 41 student workers and 38 faculty and staff would have been living Kansas if they were hired by ESU in FY 2009-10 


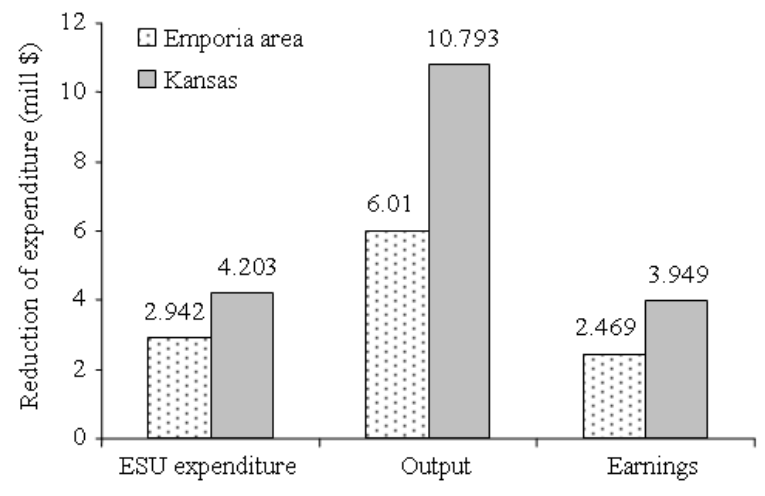

Fig. 1: Impact of ESU budget cuts on output and earnings in the Emporia Area and in Kansas, FY 2009-10

\section{DISCUSSION}

This study examines the inter-linkages of Emporia State University with the local and state economies of Kansas for applying an input-output procedure and estimated output, income and employment impacts from university budget cuts. The economic impact of University budget cuts on the local economy is reflected through the Emporia area economic multipliers. For example, University budget cuts for $\$ 2.9$ million in the Emporia Area resulted in a reduction in output by $\$ 6.0$ million hence, the output multiplier for Emporia Area is 2.04 (total change divided by the initial change). Which implies for every dollar of ESU budget cut the output is reduced by an additional $\$ 1.04$ in the Emporia Area. The earnings and employment multipliers for Emporia Area are \$1.65 and 1.61, respectively. This implies for every dollar decrease in ESU payroll there is an additional \$0.65 decrease in household income and every job loss at ESU would cause an additional 0.61 job loss in the Emporia Area. Figure 1 depicts the economic impact of ESU budget cuts on output and earnings in the Emporia Area and Kansas in terms of dollar amount.

When the impact of the University's budget cuts for the state as a whole is considered (Table 4) the output, earnings and employment multiplier are 2.56, 1.85 and 1.89 respectively. As expected all three multipliers for the state are larger than the multipliers obtained for the Emporia Area. The reason for such differences is the higher linkages of some of the economic sectors in the state economy than for the local economy. It is should be recognized that this study is a fairly conservative estimate of the impact of Emporia State University's budget cuts on the local economy because the decrease in federal and state tax revenues from fewer activities of the university and its community and the loss of students and/or programs which would have benefited the lifetime earnings by ESU graduates are not included in the study.

\section{CONCLUSION}

Studies have found that cutting funding for statefunded colleges and universities will eventually diminish the positive regional effect of the institutions $^{[7]}$. Pillis and Pillis ${ }^{[7]}$ concluded from their empirical study that the effects of budget cuts can severely impact the University's functioning and the full impact of these cuts may not be realized for decades. For example, financial pressures at the state colleges and universities could affect the quality of the educational experience by increasing the size of freshman classes to raise tuition revenues and students could find larger classes and crowded triple dorm rooms. Further, more classes might be taught by graduate students rather than full professors and colleges could also make cut in financial aids, scholarships, athletic programs, academic advising and health services ${ }^{[9]}$. The states that have lottery-funded merit aid programs such as, Georgia, Florida and West Virginia are also cutting back funding as revenue from the game are decreasing ${ }^{[8]}$. It is also observed that although private colleges also lost money as endowments have shrunk over the past year, many of them are keeping tuition increases to a minimum and offering more financial aid to remain a viable alternative to public universities. Lastly, it is mostly believed in the academic community what Prof. Robert E. Hemenway, the chancellor of the University of Kansas once said, "You can't kill off the intellectual future and be a successful state. You can't cut your way to excellence",[10].

\section{REFERENCES}

1. CAE/RAND-Council for Aid to Education (CAE), 1997. An independent subsidiary of RAND Corporation. Breaking the Social Contract: The Fiscal Crisis in Higher Education, CAE-100. http://www.rand.org/publications/CAE/CAE100/in dex.html

2. Center on Budget and Policy Priorities (CBPP), 2008. An Update on State Budget Cuts. Nicholas Johnson, Phil Oliff and Jeremy Koulish. http://www.cbpp.org/12-17-08sfp.htm 
3. Chakraborty, K. and D. Edmiston, 2003. Economic impact of university and financial consequences of university budget cuts on the local and state economy. Mount. Plains J. Bus. Econ., 4. http://www.mountainplains.org/articles/2003/gener al/MPJBE-REV.DOC

4. Chakraborty, K. and D. Edmiston, 2006. The economic impact of regional university revisited. Kansas Policy Rev., 28: 1-13.

5. CHEI-Citizens for Higher Education Inc., 2009. Board of regents approves state university tuition rates and allocates federal stimulus dollars. http://www.kansashighereducation.org/index.htm

6. Dumas, L.J., 2003. Economic multipliers and the economic impact of DOE spending in New Mexico. Study Paper.

http://nukewatch.org/facts/nwd/DumasReport0331 03.pdf

7. dePillis, E.G. and L.G. dePillis, 2007. The Longterm Impact of University Budget Cuts: A Mathematical Model. Study Paper, University of Hawaii, at Hilo.

http://www.math.hmc.edu/ depillis/REPRINTS/U nivElsevier.pdf
8. Foley, R.J., 2009. States cut aids to college students as demand booms. http://www.yahoo.com/s/as/20090812/ap_on_re_us /us_finaincial_aid_states/

9. Kahane, A., 2009. Economy impacts quality. http://www.moorparkacron/news/2009/0619/school s/028.html

10. LJWorld.com., 2009. Hemenway advises state lawmakers: You can't cut your way to excellence. http://www2.ljworld.com/2009/feb/11/universitypresidents-warn-deep-budget-cuts-will-s/

11. McNichol, Elizabeth and Iris J. Lav, 2009. State budget trouble worsen. Center on Budget and Policy Prioirties. http://www.cbpp.org/files/9-809sfp.pdf

12. Leontief. W., 1936. Qualitative input-output relations in the economic system of United States. Rev. Econ. Stat., 183: 105-125. 